\title{
Productivity of the Green Mass of New Alfalfa Cultivars Depending on the Effect of Macro- and Microfertilizers on Various Phosphorous Backgrounds
}

\author{
Saltanat Toktarbek Kyzy Toktarbekova', Galiolla Tolendinovich Meiirman², \\ Sakysh Tanyrbergenovna Yerzhanova ${ }^{2 *}$, Serik Sarbayevich Abayev², \\ Aman Kozhakhmetovich Umbetov ${ }^{1}$ \\ 1 NJSC Kazakh National Agrarian University, Almaty, 050000, Kazakhstan \\ 2 LLP Kazakh Research Institute of Agriculture and Plant Growing, Almalybak, 040909, Kazakhstan \\ * Corresponding author's e-mail: sakysh.yerzhanova@bk.ru
}

\begin{abstract}
The effect of phosphorus fertilizer on the yield of new alfalfa cultivars Kokorai, Osimtal, and Kokbalausa has been identified after the introduction of $\mathrm{P}_{0}, \mathrm{P}_{150}$, and $\mathrm{P}_{200}$ (active substance) with nitrogen $\mathrm{N}_{60}$, potassium $\mathrm{K}_{70}$, microelements (cobalt (Co), molybdenum (Mo)) on the three noted phosphorus backgrounds. Increasing the dosages of phosphorus increases the yield of the green mass of the three cultivars on various backgrounds without the introduction of any other types of fertilizers on average by $126.6 \%$ with $\mathrm{P}_{150}$, and by $35.9 \%$ with $\mathrm{P}_{200}$. The introduction of nitrogen $\mathrm{N}_{60}$ on all phosphorus backgrounds increased productivity by $112-117 \%$, the introduction of potassium $\mathrm{K}_{70}$ - by $102-110 \%$, the introduction of cobalt Co - by $113-122 \%$, and the introduction of molybdenum Mo - by $115-126 \%$. The highest productivity was observed in the Kokbalausa cultivar, the level of its green mass yield was $77.7 \mathrm{t} /$ ha after the introduction of $\mathrm{P}_{200}, 89.8 \mathrm{t} / \mathrm{ha}$ - after the introduction of $\mathrm{P}_{200} \mathrm{~N}_{60}, 82.9 \mathrm{t} / \mathrm{ha}$ - after the introduction of $\mathrm{P}_{200} \mathrm{~K}_{70}, 88.9 \mathrm{t} / \mathrm{ha}$ - after the introduction of $\mathrm{P}_{200} \mathrm{Co}$, and $-89.5 \mathrm{t} /$ ha after the introduction of $\mathrm{P}_{200} \mathrm{Mo}$. Generally, the difference between the cultivars' response to the fertilizer is weak, they all equally respond to the fertilizer.
\end{abstract}

Keywords: alfalfa, new cultivars, macrofertilizer, microfertilizer, phosphorus background, green mass yield.

\section{INTRODUCTION}

Alfalfa is a leading fodder crop in the South and South-East of Kazakhstan. In recent years, several synthetic cultivars have been developed and approved for their use in production. They are protected by copyright certificates and patents. However, the varietal potential of this crop in terms of the yield of fodder mass is not commercialized in full. The fodder value of alfalfa and its positive effect on soil fertility are more evident in the case of good grass stand, which to a great extent may be controlled using mineral, mainly phosphorus nutrition. Phosphorus fertilizers are a key factor in increasing alfalfa productivity. They are introduced both before tillage and sowing in the first year of alfalfa growth, and for additional nutrition in the second year. They are also efficient when introduced during sowing. Their role in obtaining high yields of green mass and hay has been sufficiently discussed in literature sources (Basibekov \& Gusev, 1982; Berg et al., 2005; Berg et al., 2007; Degunova \& Danilova, 2011; Ramazanova et al., 2011; Doev et al., 2015; Serekpaev et al., 2015). The average nitrogen concentration in the roots is $2 \%$. Due to the root system, 200-400 kg/ha of nitrogen accumulate in the soil horizon half a meter thick (Berg et al., 2005, Berg et al., 2007; Gorkovenko, 2012; Serekpaev et al., 2015). Microelements perform specific roles in plant metabolism, influence the enzymatic reactions, the physicochemical properties of the plasma colloids, and the use of nutrients (such as nitrogen, phosphorus, and potassium). Among microelements, the most 
important in the alfalfa exchange processes are cobalt and molybdenum (Walworth \& Summer, 1990; Kheirkhah et al., 2016). In the case of a decreased content of cobalt in the fodder (less than $0.07 \mathrm{mg} / \mathrm{kg}$ of dry weight), the productivity of farm animals reduces sharply, along with the weight gain and the milk yield. Cobalt deprivation may further cause severe disease in the cattle that is called pining, which affects cattle. The cattle lose appetite, and overall weakness is observed; the hairs become rough and hard; the content of hemoglobin in the blood decreases since cobalt is contained in vitamin $\mathrm{B}_{12}$ and is involved in hemoglobin formation (Gorkovenko, 2012; Kheirkhah et al., 2016). Microelements are important for forming the symbiotic apparatus in terms of nitrogen fixation; they stimulate the activity of nodule bacteria (Chuyanova, 2016).

The role of macro and microelements in the live activity and productivity of plants is well known, and macro and microelements are considered to be very important. However, there are little experimental data about using them for alfalfa; in this context, the research was aimed at studying the effect of macro- and microelements on the productivity of alfalfa agrocoenoses based on new local cultivars.

\section{MATERIAL AND METHODS}

The objects of the research were new alfalfa (Medicago sativa) cultivars: Kokorai, Kokbalausa, and Osimtal, allowed for use.

Alfalfa cultivar Kokorai was bred by the method of choosing the plants with the best set of economically valuable traits and overall combining ability. The initial forms were five inbred lines $\left(\mathrm{J}_{2}-132\right.$ from sample K-6940 - India, $\mathrm{J}_{2}-101$ from cultivar Kapchagayskaya $80, \mathrm{~J}_{3}-53$ from cultivar Semirechenskaya mestnaya, $\mathrm{J}_{2}$ 212 from sample K-41340 - Italy, and 23-4 from cultivar Omskaya 8893), and one heterozygous plant from cultivar Omskaya 8893. According to the competitive grade testing over two cycles, the green mass yield amounted to $641 \mathrm{~kg} / \mathrm{ha}$, of hay $-148 \mathrm{~kg} / \mathrm{ha}$, and the yield of seeds $-3.49 \mathrm{t} /$ ha, which exceeded the standard by $22.4,22.5$, and $28.3 \%$, respectively.

Alfalfa cultivar Osimtal was obtained by the method of choosing combination-valuable inbred lines and polycrossing. The cultivar includes five inbred lines: D-19/24, D-8/65 from cultivar
Dawson, C-21/14 from cultivar Semirechenskaya mestnaya, K-8-41 from cultivar Kapchagayskaya 80, and I-7/3 from cultivar Iolotanskaya 1763. According to the competitive grade testing over two cycles, the green mass yield amounted to 600 $\mathrm{kg} / \mathrm{ha}$, of hay $-133 \mathrm{~kg} / \mathrm{ha}$, and the yield of seeds $-3.8 \mathrm{t} / \mathrm{ha}$, which exceeded the standard by 25.8 , 25.5 , and $18.8 \%$, respectively.

Alfalfa cultivar Kokbalausa was obtained by the method of polycrossing with the use of the lines experimentally created from seven inbred ones: K14/27 from cultivar Kapchagayskaya 80 and C 6/33 from cultivar Semirechenskaya mestnaya, D17/09 from cultivar Dawson, I17/54 and I20/12 from cultivar Iolotanskaya 1763, P-12/02, P-14/08 from cultivar Poiton. According to the competitive grade testing over two cycles, the green mass yield amounted to $682 \mathrm{~kg} / \mathrm{ha}$, of hay $144 \mathrm{~kg} / \mathrm{ha}$, and the yield of seeds $-2.7 \mathrm{t} / \mathrm{ha}$, which exceeded the standard by $22.0,21.0$, and $28.5 \%$, respectively.

In laying the experiments, three phosphorus backgrounds were created: natural $-\mathrm{P}_{0}$ (without introducing phosphorus), and those enriched by the one-time introduction of $\mathrm{P}_{150}$ and $\mathrm{P}_{200}$; into each background, $\mathrm{N}_{60}, \mathrm{~K}_{70}$, and microelements - cobalt $\left(\mathrm{Co}_{2}\right)$ and molybdenum (Mo) - were introduced. The experiment was laid in 45 variants with three repetitions using the systematic method of variant placing:

1. Reference $\mathrm{P}_{0}$ 6. Reference $\mathrm{P}_{150} 11$. Reference $\mathrm{P}_{200}$
2. $\mathrm{N}_{60}$
3. $\mathrm{K}_{70}$
7. $\mathrm{P}_{150}+\mathrm{N}_{60}$
8. $\mathrm{P}_{150}^{150}+\mathrm{K}_{70}$
4. $\mathrm{Co}_{2}$
9. $\mathrm{P}_{150}+\mathrm{Co}_{2}$
12. $\mathrm{P}_{200}+\mathrm{N}_{60}$
13. $\mathrm{P}_{200}+\mathrm{K}_{70}$
5. $\mathrm{Mo}$
10. $\mathrm{P}_{150}+\mathrm{Mo}$
14. $\mathrm{P}_{200}+\mathrm{Co}_{2}$
15. $\mathrm{P}_{200}+\mathrm{Mo}$

The area of each plot was $30 \mathrm{~m}^{2}$. The seeds were sown without covering with the interrow distance of $30 \mathrm{~cm}$ with the seeding norm of 18 $\mathrm{kg} / \mathrm{ha}$ of germinating seeds. The dosages of fertilizers were indicated in terms of active substances (a.s.); the following types of fertilizers were used: ammophos, ammonium nitrate, potassium chloride, ammonium molybdate, and cobalt oxide.

The experimental plot was presented by light chestnut soil in upland cultivated lands formed on loess-loams with medium loamy mechanical composition. It was located in the piedmont inclined plain of the Northern slope of Ili Alatau. In general, the terrain in this area was characterized by a rather strong degree of horizontal separation by a series of branched ravines with flat and inclined slopes used in irrigated agriculture. 
The soil was characterized by relatively low humus content due to the high carbonate content; the reaction of the soil solution was slightly alkaline: the $\mathrm{pH}$ was 7.3. The absorption capacity did not exceed $15 \mathrm{mg} / \mathrm{eq}$. The humus content in the $0-30 \mathrm{~cm}$ layer was $2.31 \%$, total nitrogen $-0.190 \%$, total phosphorus $0.220 \%$, the content of alkali-hydrolyzable nitrogen in the upper soil layer was $74.2 \mathrm{mg} /$ $\mathrm{kg}$, mobile phosphorus $-20.0 \mathrm{mg} / \mathrm{kg}$, and exchange potassium $-330 \mathrm{mg} / \mathrm{kg}$ of soil. Chemical analyses were made according to the standard methods at the Department of Agricultural Chemistry and Soil Science of the Kazakh Research Institute of Farming and Crop Production (KazNIIZiR). Samples were taken in the phase of alfalfa growth, budding and flowering. The samples of the soil and the plants were taken from each plot in the experiment. The soil was sampled from the depth of $0-20 \mathrm{~cm}$. In the soil, the following was determined: ammonium - using the nitrogen photocolorimetric method with the use of the Nesslerss reagent (spectrometer PE 5300V), nitrate nitrogen - using the potentiometric method with the use of the ion-selective electrode (ion meter Expert-001), and mobile forms of phosphorus and potassium - by the Chirikov's method as modified at the Central Institute for Scientific Support for Agriculture (CINAO) (GOST 26204). The content of nitrogen, phosphorus, and potassium in the plants was determined by wet ashing in sulfuric acid with hydrogen peroxide: nitrogen - using the Kjeldahlıs method, phosphorus - using colorimetric spectrophotometer PE 5300V, and potassium - using flame photometric method FPA-2-01.

The yield of green mass was accounted for in the period of budding - beginning of flowering, starting with the first year of alfalfa life (August 10). In the first year of life, one mowing was made, in the second year - three mowings. The experimental data were statistically processed using the method of variance analysis (Dospekhov, 1985; Sheudzhen et al., 2013).

The agrotechnical conditions of cultivation were the following: main tillage - in the winter to the depth of $22-25 \mathrm{~cm}$, pre-sowing tillage involved early spring harrowing of winter tillage, cultivation with the use of an RVK tillage machine, and compacting the soil before and after sowing. The predecessor was winter wheat.

\section{RESULTS AND DISCUSSION}

In the practice of cultivating alfalfa, fertilizers are only used in individual cases, thus the desired results are not always achieved in terms of the yield of fodder mass and accumulation of root and stubble residues. With that, naturally, its role as a nitrogen accumulator through the symbiosis with the nodule bacteria is minimized. It is known that insufficient supply of phosphorus and microfertilizers to alfalfa reduces the activity of nitrogen-fixing bacteria. As to the alfalfa nitrogen nutrition, most researchers believe it is necessary to introduce it in the starter dosage dose in the year of sowing before the formation of a symbiotic relationship between alfalfa seedlings and the nodule bacteria (Rieger, 2012; Churkina, 2012). Reproduction and preservation of soil fertility can only be ensured by highly productive perennial herbs. However, high yields may be obtained only in case of observing the technology of crop cultivation, an integral component of which is a fertilizer system balanced in terms of nutrients.

The authors intended to study the effect of nitrogen, potassium, and microfertilizers (cobalt, molybdenum) with various levels of phosphorus nutrition since alfalfa yield is determined by the availability of phosphorus. The data about the green mass yield in the 45 variants where the backgrounds of $\mathrm{P}_{0}, \mathrm{P}_{150}$, and $\mathrm{P}_{200} \mathrm{~kg}$ of a.s. were created, and where the dosages of nitrogen $\mathrm{N}_{60}$, potassium $\mathrm{K}_{70}$, and microfertilizers cobalt and molybdenum were used, are shown in Table 1 for the three cultivars: Kokorai, Kokbalausa, and Osimtal.

Analyses of the obtained results on the yield of green mass for the four harvests over two years of using the grass stand show the efficiency of fertilizers with different reactions of the cultivars. Since the experimental data were derived from one experiment, the results were discussed by the studied cultivars and types, as well as the dosages of the fertilizers and the backgrounds in the same context, using the materials shown in Table 1.

Comparison of variants $\mathrm{P}_{0}$ (without phosphorus fertilizer), $\mathrm{P}_{150}$, and $\mathrm{P}_{200}$ that were adopted as the backgrounds shows the efficiency of increasing the dosages of phosphorus. With $\mathrm{P}_{0}$, the yield of Kokorai cultivar green mass amounted to 53.4 $\mathrm{t} /$ ha $(100 \%)$, with $\mathrm{P}_{150}-68.1 \mathrm{t} / \mathrm{ha}(127.5 \%)$ and with $\mathrm{P}_{200}-74 \mathrm{t} / \mathrm{ha}(138.5 \%)$, of the Kokbalausa cultivar - 59.5 t/ha (100\%), 74.2 t/ha (124.7\%), and $77.7 \mathrm{t} / \mathrm{ha}(130.6 \%)$, and of the Osimtal cultivar $-48.2 \mathrm{t} / \mathrm{ha}(100 \%), 61.8 \mathrm{t} / \mathrm{ha}(128.2 \%)$, and 
Table 1. The effect of macro- and microfertilizers on the yield of alfalfa green mass sown in 2017, data for the years 2017-2018

\begin{tabular}{|c|c|c|c|c|c|c|}
\hline \multirow[b]{2}{*}{ Variant } & \multirow{2}{*}{$\begin{array}{c}\text { In the year } 0 \\
\text { sowing }\end{array}$} & \multicolumn{3}{|c|}{ The second year of life } & \multirow[b]{2}{*}{ Total, t/ha } & \multirow[b]{2}{*}{$\%$} \\
\hline & & $\begin{array}{c}\text { First } \\
\text { mowing }\end{array}$ & $\begin{array}{l}\text { Second } \\
\text { mowing }\end{array}$ & $\begin{array}{c}\text { Third } \\
\text { mowing }\end{array}$ & & \\
\hline \multicolumn{7}{|c|}{ Background $\mathrm{P}_{0}$ (without introducing phosphorus), cultivar Kokorai } \\
\hline $\mathrm{P}_{0}$ & 10.4 & 19.3 & 13.5 & 13.5 & 53.4 & 100 \\
\hline Background $+\mathrm{N}_{60}$ & 11.0 & 21.9 & 15.5 & 14.3 & 62.7 & 117 \\
\hline Background $+\mathrm{K}_{70}$ & 10.7 & 20.8 & 14.9 & 12.4 & 58.8 & 110 \\
\hline Background + Co & 12.3 & 22.6 & 15.5 & 13.2 & 63.6 & 119 \\
\hline Background + Mo & 12.5 & 23.0 & 16.2 & 14.5 & 66.2 & 124 \\
\hline \multicolumn{7}{|c|}{ Background $\mathrm{P}_{150}$, cultivar Kokorai } \\
\hline$P_{150}$ & 11.4 & 24.7 & 16.7 & 15.3 & 68.1 & 100 \\
\hline Background $+\mathrm{N}_{60}$ & 11.6 & 27.9 & 20.2 & 18.2 & 77.9 & 114 \\
\hline Background $+\mathrm{K}_{70}$ & 11.0 & 26.4 & 17.2 & 16.1 & 70.7 & 104 \\
\hline Background + Co & 12.3 & 28.2 & 19.4 & 17.4 & 77.3 & 114 \\
\hline Background + Mo & 12.4 & 29.9 & 20.9 & 18.3 & 81.5 & 120 \\
\hline \multicolumn{7}{|c|}{ Background $\mathrm{P}_{200}$, cultivar Kokorai } \\
\hline$P_{200}$ & 13.2 & 25.6 & 18.0 & 17.2 & 74.0 & 100 \\
\hline Background $+\mathrm{N}_{60}$ & 13.5 & 29.4 & 20.3 & 18.6 & 81.8 & 111 \\
\hline Background $+\mathrm{K}_{70}$ & 12.6 & 27.9 & 18.7 & 17.5 & 76.7 & 104 \\
\hline Background + Co & 13.8 & 29.7 & 21.2 & 18.6 & 83.3 & 113 \\
\hline Background + Mo & 14.5 & 30.0 & 21.4 & 20.0 & 85.9 & 116 \\
\hline \multicolumn{7}{|c|}{ Background $\mathrm{P}_{0}$ (without introducing phosphorus), cultivar Kokbalausa } \\
\hline $\mathrm{P}_{0}$ & 12.3 & 21.0 & 14.1 & 12.1 & 59.5 & 100 \\
\hline Background $+\mathrm{N}_{60}$ & 12.8 & 24.2 & 16.6 & 15.4 & 69.0 & 116 \\
\hline Background $+\mathrm{K}_{70}$ & 12.1 & 22.3 & 14.6 & 12.6 & 61.6 & 104 \\
\hline Background + Co & 13.6 & 25.6 & 16.9 & 14.1 & 70.2 & 118 \\
\hline Background + Mo & 14.0 & 25.2 & 16.9 & 14.3 & 70.4 & 118 \\
\hline \multicolumn{7}{|c|}{ Background $\mathrm{P}_{150}$, cultivar Kokbalausa } \\
\hline$P_{150}$ & 13.3 & 8.0 & 17.6 & 15.3 & 74.2 & 100 \\
\hline Background $+\mathrm{N}_{60}$ & 13.8 & 33.3 & 20.6 & 18.3 & 86.0 & 116 \\
\hline Background $+\mathrm{K}_{70}$ & 12.9 & 9.4 & 17.6 & 15.6 & 75.5 & 102 \\
\hline Background + Co & 13.9 & 2.8 & 20.4 & 18.1 & 85.2 & 115 \\
\hline Background + Mo & 14.4 & 33.6 & 20.6 & 18.4 & 87.0 & 117 \\
\hline \multicolumn{7}{|c|}{ Background $\mathrm{P}_{200}$, cultivar Kokbalausa } \\
\hline$P_{200}$ & 14.2 & 8.5 & 18.6 & 16.4 & 77.7 & 100 \\
\hline Background $+\mathrm{N}_{60}$ & 14.8 & 33.0 & 21.9 & 20.1 & 89.8 & 116 \\
\hline Background $+\mathrm{K}_{70}$ & 14.0 & 1.4 & 19.9 & 17.6 & 82.9 & 107 \\
\hline Background + Co & 15.1 & 33.9 & 21.9 & 18.0 & 88.9 & 114 \\
\hline Background + Mo & 14.6 & 34.5 & 22.1 & 18.3 & 89.5 & 115 \\
\hline \multicolumn{7}{|c|}{ Background $\mathrm{P}_{0}$ (without introducing phosphorus), cultivar Osimtal } \\
\hline $\mathrm{P}_{0}$ & 10.0 & 8.5 & 11.7 & 8.0 & 48.2 & 100 \\
\hline Background $+\mathrm{N}_{60}$ & 11.2 & 1.1 & 13.6 & 9.0 & 54.9 & 114 \\
\hline Background $+\mathrm{K}_{70}$ & 10.3 & 0.2 & 12.2 & 8.6 & 51.3 & 106 \\
\hline Background + Co & 12.4 & 1.8 & 14.0 & 10.4 & 58.6 & 122 \\
\hline Background + Mo & 12.8 & 2.4 & 14.4 & 11.2 & 60.8 & 126 \\
\hline \multicolumn{7}{|c|}{ Background $\mathrm{P}_{150}$, cultivar Osimtal } \\
\hline $\mathrm{P}_{150}$ & 11.3 & 23.1 & 15.0 & 12.4 & 61.8 & 100 \\
\hline Background $+\mathrm{N}_{60}$ & 11.7 & 27.0 & 17.3 & 14.0 & 70.0 & 113 \\
\hline Background $+\mathrm{K}_{70}$ & 10.8 & 25.9 & 16.2 & 13.7 & 66.6 & 108 \\
\hline Background + Co & 12.4 & 27.7 & 17.9 & 14.6 & 72.6 & 117 \\
\hline Background + Mo & 12.5 & 28.4 & 18.2 & 14.9 & 74.0 & 120 \\
\hline \multicolumn{7}{|c|}{ Background $\mathrm{P}_{200}$, cultivar Osimtal } \\
\hline$P_{200}$ & 13.8 & 24.0 & 15.7 & 13.7 & 67.2 & 100 \\
\hline Background $+\mathrm{N}_{60}$ & 14.0 & 28.3 & 18.7 & 14.0 & 75.0 & 112 \\
\hline Background $+\mathrm{K}_{70}$ & 14.2 & 26.4 & 16.6 & 15.3 & 72.5 & 108 \\
\hline Background + Co & 15.3 & 27.4 & 18.5 & 16.0 & 77.2 & 115 \\
\hline Background + Mo & 15.3 & 28.1 & 18.2 & 16.1 & 77.7 & 116 \\
\hline Experiment accuracy, \% & - & - & - & - & 2.2 & - \\
\hline LSD $_{0.95}$ & - & - & - & - & 6.5 & - \\
\hline
\end{tabular}


$67.2 \mathrm{t} / \mathrm{ha}(139.4 \%)$, respectively. Thus, the rate of introducing phosphorus fertilizers is the main factor in increasing the yield rate of alfalfa, which increases with increasing the dosage.

On the background of various dosages of phosphorus fertilizer $\mathrm{P}_{0}, \mathrm{P}_{150}$, and $\mathrm{P}_{200}$, the use of nitrogen in the dosage of $\mathrm{N}_{60}$ of a.s. increases the yield rate of alfalfa cultivars in the range of $11-17 \%$. Here varietal specificity is weakly expressed, a slight advantage in the Kokorai cultivar is observed.

The use of potassium at the dosage of $\mathrm{K}_{70}$ on the three phosphorus backgrounds provides a slight increase in the studied cultivars in the range of $2-10 \%$, which cannot be adopted as a veracious value. A conclusion may be drawn that the content of potassium in the soil is sufficient.

The use of cobalt trace element ensured a significant increase in the green mass yield on all studied phosphorus backgrounds and cultivars. It was observed that in all cultivars on the background without introducing phosphorus, the increase caused by cobalt was more significant, for instance, for the Kokbalausa cultivar it amounted to $19 \%$, for the Kokbalausa cultivar - to $18 \%$, and for the Osimtal cultivar - to $22 \%$. In general, on all phosphorus backgrounds, the increase in the yield of the green mass caused by cobalt was in the range between 13 and $22 \%$. No varietal specificity was detected for cobalt.

The use of microelement molybdenum also contributed to increasing the yield of alfalfa green mass on all studied phosphorus backgrounds. The manifestations of molybdenum efficiency on the background without the introduction of phosphorus were more obvious with cultivars Kokbalausa and Kokorai - 118-126\%, than with cultivar Osimtal. In general, an increase of the yield by $115-126 \%$ was observed after introducing cobalt on all backgrounds and for all cultivars.

\section{CONCLUSION}

Depending on the norms of introduction, mineral fertilizers help increase the content of nitrogen and mobile phosphorus. Including microelements in the system of fertilizer has a positive effect on the content of nitrate ammonium in the soil.

The experiment for determining the effect of phosphate fertilizers on forming the alfalfa fodder productivity with the use of cultivars has been laid for the first time. Moreover, the new breed cultivars allowed for use in production are increasingly used at farms in the South and SouthEast of Kazakhstan. High efficiency of phosphorus for increasing the yield rate of green mass has been determined. The introduction of the starting dosage of nitrogen into alfalfa crops also promotes the formation of a strong grass stand. The introduction of potassium had no effect due to its sufficient content in the soil.

High efficiency of introducing microelements - cobalt and molybdenum - has been determined; obviously, they increase the symbiotic activity of the nodule bacteria. The varietal specificity of alfalfa to the fertilizers and microelements is weak.

It is recommended to use macro- and microelements on a larger scale for increasing the yield rate of fodder mass and improving the crop rotation value of the crop, since alfalfa is a leading component in the structure of acreage in irrigated agriculture.

In the conditions of stationary experiment, the authors determined the optimal dosages of macrofertilizers and their best combinations with microfertilizers that ensured the formation of the maximum high-quality alfalfa green mass yield rate. The practical relevance of the research is in developing a system of fertilizers for alfalfa that would ensure the optimum mineral nutrition and the maximum yield rate of alfalfa agrocoenosis, and improving the quality of the green mass.

\section{REFERENCES}

1. Basibekov B.S., Gusev, V.N. 1982. Lyutserna (Alfalfa). In: Scientific bases and recommendations for using fertilizers in Kazakhstan. Kaynar, Alma-Ata, 124-128.

2. Berg W.K., Cunningham S.M., Browder S.M., Jern B.S., Johnson C.D., Santini J., Wolenz J.J. 2005. The effect of phosphorus and potassium on productivity and components alfalfa. Crop Science, 45, 297-304.

3. Berg W.K., Cunningham S.M., Browder S.M., Jern B.C., Johnson C.D., Santini J.B., Wolenz J.J. 2007. Long-term effects of phosphorus and potassium fertilization on crop yields and components alfalfa harvest. Crop Science, 47, 2198-2209. DOI: 10.2135 / cropci 2006.09.05. 0576

4. Churkina G.N. 2012. Efficiency of biological nitrogen fixation in new legume cultivars [in Russian]. Biotechnology. Theory and practice, 12, 66-72.

5. Chuyanova G.I. 2016. Dependence of fodder crops productivity on the content of molybdenum in the soil [in Russian]. Bulletin of the Omsk State 
Agrarian University, 1(21), 52-57.

6. Degunova N.B., \& Danilova Y.B. 2011. The yield rate of variegated alfalfa green mass depending on seeds inoculation with biopreparations [in Russian]. Agrarian Russia, 5, 23-25.

7. Doev D.N., Tsotsieva V.P., \& Basieva L.G. 2015. Biological nitrogen share in Lucerne plants nutrition depending on the activeness of nodule bacteria strain. The scientific almanac of the countries of the Black Sea region, Rostov-on-Don, 4(4), 34-37.

8. Dospekhov B.A. 1985. Field technique [in Russian]. Moscow.

9. Gorkovenko L.G. 2012. Efficiency of starter dosages of nitrogen fertilizers on the crops of variegated alfalfa [in Russian]. Forage production, 4, 16-17.

10. Kheirkhah M., Madani H., Lac S., Nourmohammadi G., Mojaddam M. 2016. Response of alfalfa forage to phosphorus, boron, and manganese-based fertilizing systems. Journal of Experimental Biology and Agricultural Sciences, 4(IV), 398-405.

11. Ramazanova S.B., Mayirman G.T., Suleimenov E.T., Baymaganova G.S. 2011. The use of fertilizers in cultivating seed alfalfa in the South-East of Kazakhstan [in Russian]. Recommendations. KazNIIZiR.

12. Rieger A.N. 2012. Nitrogen fertilizers - important factors in forming the grass stand, formation of modules and productivity of creeping alfalfa [in Russian]. Collection of scientific works of the AllRussian Scientific Research Institute of Sheep and Goat Breeding, 3(1-1), 170-172.

13. Serekpaev N.A., Sagalbekov S.K., Makhanova S.K. 2015. The yield rate of green mass and its relation with plant height and leafiness in alfalfa hybrids at a competitive grade testing nursery [in Russian]. News of the National Academy of Sciences of the Republic of Kazakhstan series of Agricultural sciences, 2(26), 97-103.

14. Sheudzhen A.H., Bondareva T.N., Kizinek S.V. 2013. Agrochemical bases of using fertilizers [in Russian]. Agriculture and forestry. Agrochemistry. Poligraf-Yug, Maykop.

15. Walworth J.L., Summer M.E. 1990. Alfalfa response to lime, phosphorus, potassium, magnesium, and molybdenum on acid ultisols. Nutrient Cycling in Agroecosystems, 67-172. 